\title{
THE INFLUENCE OF CALCIUM HYPOCHLORITE DOSAGE ADJUSTMENT ON TAPIOCA WASTEWATER PRE-CHLORINATION TOWARD EFFICIENCY OF ACTIVATED SLUDGE TREATMENT
}

\section{PENGARUH PENGATURAN DOSIS KAPORIT DALAM PROSES PREKLORINASI LIMBAH CAIR TAPIOKA TERHADAP EFISIENSI PENGOLAHAN AERASI LUMPUR AKTIF}

\author{
Happy Mulyani ${ }^{1 *}$, Guruh Sri Pamungkas ${ }^{2}$ \\ ${ }^{1}$ Program Studi Teknik Kimia, Fakultas Teknik, Universitas Setia Budi, Surakarta, Indonesia \\ ${ }^{2}$ Program Studi Analis Kesehatan, Fakultas Ilmu Kesehatan, Universitas Setia Budi, Surakarta, \\ Indonesia \\ *email: cahtekim@yahoo.com
}

Received 8 June 2016; Accepted 23 September 2016; Available online 29 November 2016

\begin{abstract}
The objectives of this research are to study about influence of calcium hypochlorite dosage adjustment on tapioca wastewater chlorination toward efficiency of activated sludge treatment especially at MLVSS profile and percentage of COD removal. This research mainly divided into pre-chlorination and activated sludge treatment. Pre-chlorination taken place for 60 minutes at $\mathrm{pH}$ 8. The variation of calcium hypochlorite dosages which used are 58, 59, and $60 \mathrm{mg} / \mathrm{L}$. Prechlorination effluent with no free chlorine residual then becomes activated sludge treatment influent. Sampling has done each aeration time interval 0,2, 4, and 6 hour for analysis of COD and MLVSS content. Research result generally shows that addition of aeration time for each variation of calcium hypochlorite dosage will increase MLVSS and decrease COD content. Smallest value of COD effluent could achieved in the activated sludge treatment with calcium hipochlorite dosage 60 $\mathrm{mg} / \mathrm{L}$ addition at influent during 4 hours aeration time. Addition of $58 \mathrm{mg} / \mathrm{L}$ calcium hypochlorite results highest MLVSS and percentage of COD removal.
\end{abstract}

Key words: Activated Sludge Treatment, Calcium Hypochlorite Dosage, COD, MLVSS Prechlorination, Tapioca Wastewater

\section{ABSTRAK}

Tujuan penelitian ini adalah untuk mempelajari pengaruh pengaturan dosis kaporit terhadap efisiensi proses aerasi lumpur aktif terutama profil COD dan MLVSS tiap waktu operasi serta persentase penurunan kadar COD. Penelitian ini utamanya terbagi atas tahapan pre-klorinasi dan aerasi lumpur aktif. Preklorinasi berlangsung selama 60 menit pada $\mathrm{pH}$ 8. Variasi dosis kaporit yang digunakan yaitu 58, 59, dan $60 \mathrm{mg} / \mathrm{L}$. Efluen preklorinasi yang sudah tidak mengandung sisa klor bebas kemudian menjadi influen proses aerasi lumpur aktif. Pengambilan sampel dilakukan tiap interval waktu operasi 0, 2, 4, dan 6 jam untuk analisis kadar MLVSS dan COD. Hasil penelitian secara umum menunjukkan bahwa penambahan waktu aerasi untuk tiap variasi dosis kaporit akan makin meningkatkan kadar MLVSS dan menurunkan kadar COD. Kadar COD efluen terendah dihasilkan pada proses aerasi lumpur aktif dengan variasi dosis kaporit $60 \mathrm{mg} / \mathrm{L}$ pada waktu aerasi 4 jam. Penambahan dosis kaporit sebesar $58 \mathrm{mg} / \mathrm{L}$ akan menghasilkan kadar MLVSS tertinggi pada proses aerasi lumpur aktif dengan persentase penurunan kadar COD efluen terbesar.

Kata kunci: Aerasi Lumpur Aktif, Dosis Kaporit, COD, MLVSS, Limbah Cair Tapioka, Preklorinasi

\section{INTRODUCTION}

Tapioca wastewater is highly organic. Range of the organic content of this waste is about 3000-7500 and 7000$30000 \mathrm{mg} / \mathrm{L}$, respectively in Biological Oxygen Demand (BOD5) and Chemical 
Oxygen Demand (COD). If they are not properly treated before the disposal into receiving water body, some significant environmental hazards such unpleasant smell, oxygen depletion, and unbalance of aquatic biota will occur (Setyawati, Hirayama, Kaneko, \& Hirayama, 2011).

Activated sludge treatment could remove organic content in wastewater significantly only at the short time. Operation of this aerobic wastewater treatment method during five hours aeration able to decrease COD content in tapioca wastewater from initial condition, approximately $3000 \mathrm{mg} / \mathrm{L}$, until meet the standard quality (Santoso, 2010).

Unfortunately, the application of aerobic treatment for handling wastewaters containing COD over 4000 $\mathrm{mg} / \mathrm{L}$ can not produce effluents that comply with effluent discharge limit Furthermore, there exist cross over points, ranging from 600 to $1400 \mathrm{mg} / \mathrm{L}$ influent wastewater COD, which are crucial for effective functioning of aerobic treatment systems (Chan, Chong, Chung, \& Hassel, 2009).

The use of anaerobic systems as a high organic strength wastewater pretreatment have been succesfully employed. Anaerobic-aerobic processes can lead to a reduction both in operating costs and amount of aerobic sludge when compared with aerobic treatment alone (Chan, Chong, Chung, \& Hassel, 2009). Mulyani, Sasongko, \& Soetrisnanto (2012) also have found that application of one of high rate anaerobic system, Anaerobical Baffled Reactor (ABR), can reduce COD content of tapioca wastewater from $8000 \mathrm{mg} / \mathrm{L}$ until 954 $\mathrm{mg} / \mathrm{L}$.

However, long retention time still becomes main obstacle to the application of high rate anaerobic systems for treatment of industrial wastewater containing high organics. In order to decrease COD content of tapioca wastewater until level which aerobic treatment system can work effectively, it still needs 9 days operation of ABR system (Mulyani, Sasongko, and Soetrisnanto, 2012).

To overcome this problem, the study of tapioca wastewater pre-chlorination feasibility as an alternative pretreatment prior to activated sludge treatment should be done. Due to their fast reaction and low cost, chlorine compound, especially calcium hypochlorite, is globally the most used chemical oxidant which can remove organic pollutants found in water significantly.

The study about pre-chlorination application in tapioca wastewater treatment has done by many researcher. Optimum condition of this process has investigated. Riyanti, Lukitowati, \& Afrilianza (2010) found that tapioca wastewater pre-chlorination will result in highest COD percentage removal having value $89 \%$ at following conditions: dosage $5 \mathrm{mg}$ calcium hypochlorite/100 $\mathrm{mL}$ waste, operation $\mathrm{pH} 8$, and contact time 1 hour. On the other side, as a result of calcium hypochlorite addition using dosage based on stoichiometry reaction between chlor $\left(\mathrm{Cl}_{2}\right)$ and cyanide $\left(\mathrm{CN}^{-}\right)$on tapioca wastewater, the significant decrease of COD content which achieve $97.125 \%$ occur. Effluent of this process also known has higher BOD5/COD ratio value (Mulyani, Sasongko, \& Soetrisnanto, 2012). This condition gives a benefit. Greater BOD5/COD ratio value will make wastewater become easier to handle by biological means (Chan, Chong, Chung, \& Hassel, 2009). In addition, tapioca wastewater chlorination using calcium hypochlorite dosage until $5,986 \mathrm{mg} / \mathrm{L}$ (ratio of $\mathrm{Cl}_{2}: \mathrm{CN}^{-}=1,75$ stoichiometry reaction) also has proven result in effluent with no Tri Halo Methane detected (Mulyani and Prasadja, 2014).

However, when calcium hypochlorite dissolved in water, it will be converted to hypochlorite acid $(\mathrm{HOCl})$ and hypochlorite ion $\left(\mathrm{OCl}^{-}\right)$which very reactive to bacterial cell especially at high concentration (Parga, Shukla. \& Pedroza, 
2003). So, the addition of calcium hypochlorite must be controlled to avoid excessive dosage which can kill organic degrading microorganism in activated sludge. Hence, it is important to study about the influence of calcium hypochlorite dosage adjustment on tapioca wastewater into profil of substrate degradation and microorganisms growth during activated sludge treatment which expressed respectively in COD and Mixed Liquor Volatile Suspended Solid (MLVSS).

\section{EXPERIMENTAL METHODS}

\section{Materials and Instruments}

The main materials which used in this process research consist of tapioca wastewater, activated sludge inoculum seed, $\mathrm{Ca}(\mathrm{OCl})_{2}$, and $\mathrm{Ca}(\mathrm{OH})_{2}$. While the main instruments are jerry can, cool box, ice cube, HDPE plastic drums for chlorination and aeration process, aerator, bubble stone, $\mathrm{pH}$ meter, and comparator chlor.

\section{Procedure for Experiment}

This research divided as four steps such sampling, handling, and characteristic analysis of wastewater, calculation of reagent needs, chlorination, and activated sludge treatment. The scheme process of this research could be shown in Figure 1.

\section{Sampling, Handling, and Characteristic Analysis of Wastewater}

Tapioca wastewater was taken from one of tapioca starch small industry in Margoyoso, Pati, Central Java, Indonesia. While activated sludge inoculum seed was obtained from tapioca wastewater activated sludge aeration treatment installation which also located in Margoyoso. In order to avoid significant change in quality, wastewater and activated sludge were stored in cool box at $4{ }^{\circ} \mathrm{C}$.
Characteristic analysis was taken to assess the $\mathrm{pH}$ and COD for tapioca wastewater and VSS both for tapioca wastewater and activated sludge inoculum seed. $\mathrm{pH}$ value was analysed using electrometry method in SNI 06-6989.112004. COD analiysis procedure was done using titrimetric method based on SNI 066989.15-2004. VSS content was determinated by gravimetric method refers to APHA 2540 E-2005.

\section{Calculation of Reagen Needs}

The formula to calculate calcium hypochlorite amount which must be added for chlorination is:

$$
\mathrm{C}=\left(C_{1} \times W\right) /\left(1000 \times C_{2}\right)
$$

$\mathrm{C}$ : The amount of calcium hypochlorite

$0.1 \%$ required $(\mathrm{mL})$

$\mathrm{C}_{1}: \mathrm{Cl}_{2}$ dosage variation

$\mathrm{W}$ : Volume of wastewater treated $(\mathrm{mL})$

$\mathrm{C}_{2}: \mathrm{Cl}_{2}$ content in calcium hypochlorite

$0.1 \%(\mathrm{~mL})$

To determine $\mathrm{Cl}_{2}$ content in calcium hypochlorite solution, iodometric titrimetric method was applied. Then, titration of $100 \mathrm{ml}$ of mixture of tapioca wastewater and calcium hypochlorite with volume ratio based on calcuation in Equation 1 until reach $\mathrm{pH} 8$ was become a method to determine the amount of calcium hydroxide required.

\section{Pre-chlorination}

Pre-chlorination process was operated by mixing $20 \mathrm{~L}$ mixture of tapioca wastewater, calcium hypochlorite $0,1 \%$, and $\mathrm{Ca}(\mathrm{OH})_{2} \quad 1 \%$ based on calculation of reagen needs which has explained before in HDPE plastic drum with capacity $30 \mathrm{~L}$. Operation conditions for these process consist of contact time 60 minutes, $\mathrm{pH} 8$, and variation of $\mathrm{Cl}_{2}$ dosage applied 58, 59, and $60 \mathrm{mg} / \mathrm{L}$. Effluent of the pre-chlorination process is ready for use as feed for activated sludge treatment when has proven containing no free chlorine residual. 


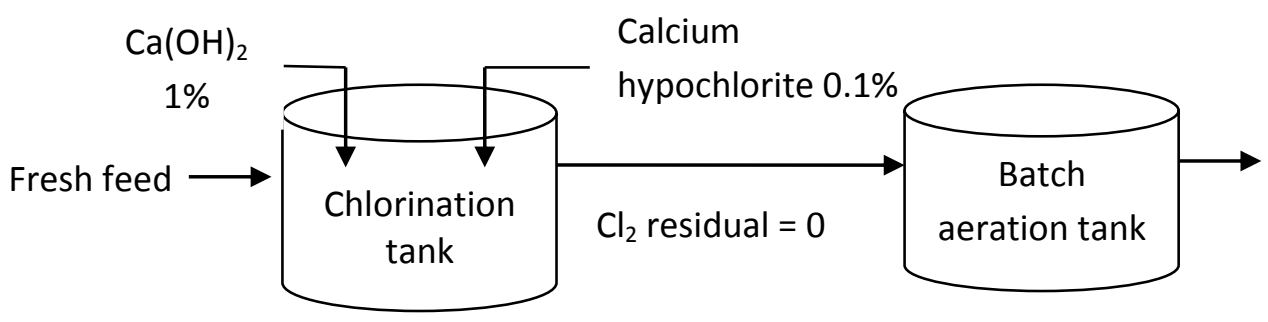

Figure 1. The research process scheme

\section{Activated Sludge Treatment}

These processes consist of three main stages such innoculation, acclimatization, and activated sludge treatment operation. HDPE plastic drum having capacity $30 \mathrm{~L}$ was used as aeration tank for this research. In innoculation, activated sludge seed inoculum was filled into the tank until achieves $1 / 3$ of working volume $(6 \mathrm{~L})$. Then, effluent of chlorination with no free chlorine residual detected was added until volume of mixture of activated sludge and wastewater reaches $18 \mathrm{~L}$.

In order to make microorganisms in activated sludge could work stable to decompose organic content in wastewater, acclimatization was done three times. Each cycle of this process consists of such stages as addition of wastewater into aeration tank containing activated sludge inoculum until ratio of activated sludge:wastewater 1:2 was achieved, aeration during 6 hours, settling for 30 minutes, and wastewater draining from the tank.

The operation of activated sludge treatment divided into three main steps i.e. (1) adding wastewater into aeration tank containing acclimatized activated sludge, aerating the mixture, and (3) COD and MLVSS analysis. Sampling of the mixture has done for COD and MLVSS requirement analysis at interval aeration time $0,2,4$, and 6 hour. For COD determination, the sample is a liquid which produced by settling the mixture during 30 minutes.

\section{RESULTS AND DISCUSSIONS}

\section{Tapioca Wastewater Characteristic}

Table 1 shows comparison between tapioca wastewater characteristic and their quality standards which belong to the Central Java Provincial Act No. 10/2004. In order to adjust tapioca wastewater characteristic until comply with this regulation, there is an urgent need to develop simple and efficient technologies for handling cassava wastewater before discharging into the environment.

Aerobic biological processes, especially activated sludge treatment, are the most commonly used in the treatment of organic wastewaters for achieving high degree of treatment efficiency. Unfortunately, aerobic systems are suitable for the treatment of wastewaters containing COD less than $1000 \mathrm{mg} / \mathrm{L}$. Highly polluting industrial wastewaters are preferably treated in an anaerobic reactor as pretreatment due to activated sludge treatment cost reduction especially in disposal sludge, nutrient requirement, and energy for aeration (Chan, Chong, Chung, \& Hassel, 2009, 2009).

Table 1. The comparison between tapioca wastewater characteristics and their quality standards

\begin{tabular}{ccc}
\hline Parameter & Current Study & $\begin{array}{c}\text { Quality standard based on The Central } \\
\text { Java Provincial Act No. 10/2004 }\end{array}$ \\
\hline $\mathrm{COD}(\mathrm{mg} / \mathrm{L})$ & 28026 & 300 \\
$\mathrm{pH}$ & 5.8 & $6-9$ \\
\hline
\end{tabular}


Table 2. Effluent quality of pre-chlorination process

\begin{tabular}{ccc}
\hline $\begin{array}{c}\text { Calcium hypochlorite } \\
\text { dosage }(\mathbf{m g} / \mathbf{L})\end{array}$ & COD $(\mathbf{m g} / \mathbf{L})$ & $\begin{array}{c}\text { Percentage of COD } \\
\text { removal }(\%)\end{array}$ \\
\hline $\begin{array}{c}\text { No addition } \\
\text { (initial condition) }\end{array}$ & 28026 & - \\
58 & 12166 & 56.59 \\
59 & 10428 & 62.79 \\
60 & 3476 & 87.60 \\
\hline
\end{tabular}

However, the main obstacles of anaerobic systems i.e. low percentage of COD decrease, long time process, and the potency of malodorous formation make their application be uneffective. In order to substitute anaerobic systems role as activated sludge pretreatment process, chlorination could be an alternative solution. Preliminary research has done by author shows that calcium hypochlorite addition to tapioca wastewater prior to entrance into the biological treatment could reduce COD content of its effluent significantly at the shorter time (Mulyani, Sasongko, \& Soetrisnanto, 2012). $\mathrm{Cl}_{2}$ injection has also proven successfull in killing organisms causing poor sludge settling, increasing the removal efficiency of Total Suspended Solid (TSS) and Biological Oxygen Demand (BOD) (Salem, Mostafa, \& Ibrahim, 2014), and reducing the biological excess sludge in the activated sludge treatment (Takdastan, Azimit, \& Jaafarzadeh, 2009).

\section{The Effluen Quality of Chlorination Process}

The influence of calcium hypochlorite dosages in tapioca wastewater chlorination into COD content of its effluen was shown in Table 2. It shows that calcium hypochlorite could decrease organic content of this sewage significantly represented by high percentage of removal COD. It mainly caused by powerful oxidizing properties of chlorine compound. Most of the organic matter will be oxidized during chlorination (Deborde and Gunten, 2008; Pickup, 2010).
The percentage of COD removal which resulted from chlorination study which operated in $\mathrm{pH} 8$ also high, ranging from $56.59-87.6 \%$ only for contact time 60 minute. This was related to the fact that oxidation is the dominant process in chlorination which occured in rapid reaction (Pickup, 2010). In addition, there is not also a part of the active chlorine taking part in chlorination of tapioca wastewater to create halogenated organic by-products (Mulyani and Prasadja, 2014).

\section{COD Effluent Profile During Activated Sludge Treatment Process}

COD effluent profile during activated sludge treatment process is presented in Figure 2. Generally, this profile shows that COD effluent content will continue to decrease along addition of aeration time. Mixing which occured in this process will intimate contact between wastewater and microorganims in activated sludge. Aeration also provide more available oxygen for life processes of organism, which degrade the organic compound contained in the wastewater and ensure microorganism in activated sludge become more favorable aerobic condition. Under this condition, the microorganism will oxidize the organic matter to convert it into $\mathrm{CO}_{2}$ that can escape to the atmosphere and into biomass that can be removed by settling (Subramani and Alulalan, 2012; Elmagd and Mahmoud, 2014. 


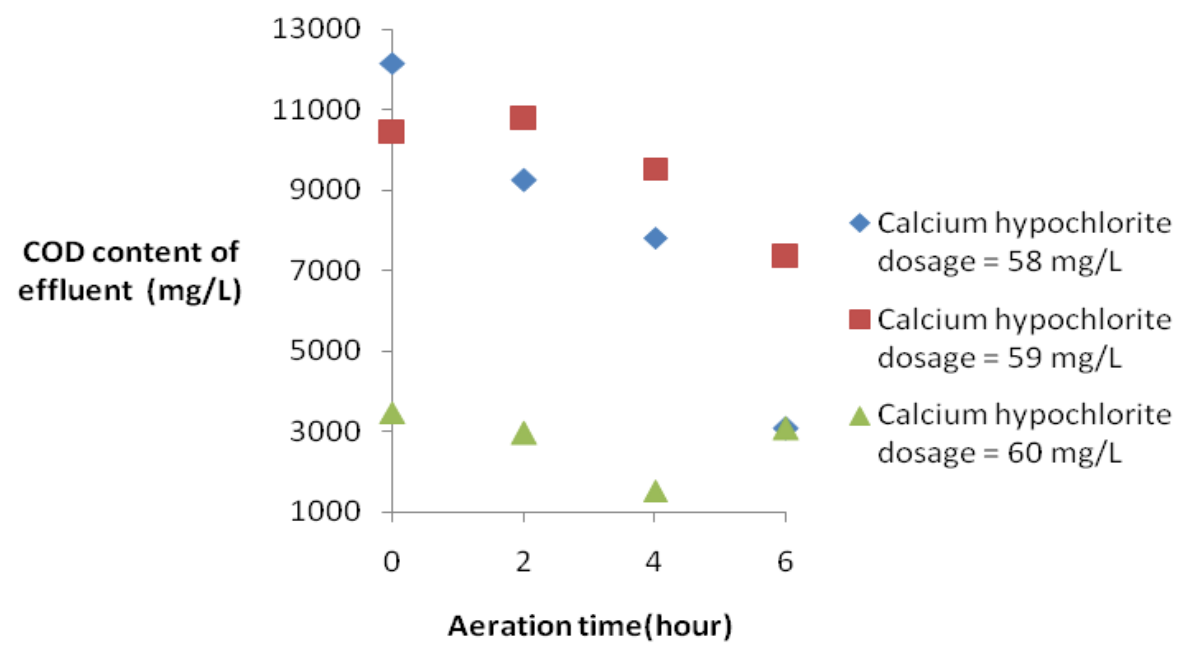

Figure 2. The relationship between aeration time and COD effluent in tapioca wastewater activated sludge treatment

Figure 2 also shows that more aeration time has lead to more organic content being converted which expressed by lower effluent COD. It phenomenon primarily indicated because of the increased contact time between the microorganisms and the substrate. If the retention time is much too short, there is a great risk that the microorganisms will not manage to grow at the rate at which material is removed from the process (Schuner and Jarvis, 2009) especially due to poor condition of oxygen dissolved concentration ( $\mathrm{Ji}$, Yang, Chen, Wang, \& Zhu, 2016).

Smallest COD was resulted from 4 hours operation of activated sludge treatment with effluent of tapioca wastewater chlorination using $60 \mathrm{mg} / \mathrm{L}$ calcium hypoclorite as influent. It was assumed would occur because this activated sludge process variation has lowest organic content of tapioca wastewater influent as shown in Table 2. This indication was supported by previous research result which mention that COD effluent in the biological treatment of tapioca wastewater become smaller as the COD influent increase (Ferraz, Bruni, \& Bianchi, 2009).

However, effluent COD in tapioca wastewater activated sludge treatment with the lowest influent COD becomes increase after 4 hours aeration. This trend was indicated caused by no significance increase of MLVSS concentration in the aeration tank after this time. It was strengthened by Kumar and his partner researchs. They stated that the reason for this case is due to lower number of microorganisms present in the aeration tank represented by smaller value of MLVSS (Kumar, Singh, Dastidar, \& Sreekrishnan, 2014).

In other side, when viewed from the percentage of COD removal, the usage of smallest calcium hypochlorite dosage variation for tapioca wastewater pretreatment prior to activated sludge treatment gives bigger value. Figure 3 shows this illustration. It was probably related to the fact that the addition of smallest calcium hypochlorite dosage into tapioca wastewater has proven results in highest COD content. It suits with Kumar, Singh, Dastidar, \& Sreekrishnan, (2014) which state that the MLVSS which representing the number of organic degrading microorganism will decrease when the feed concentration of organic was decreased. Moreover, higher concentration of organic degrading microorganisms will give the faster COD decrease rate. 


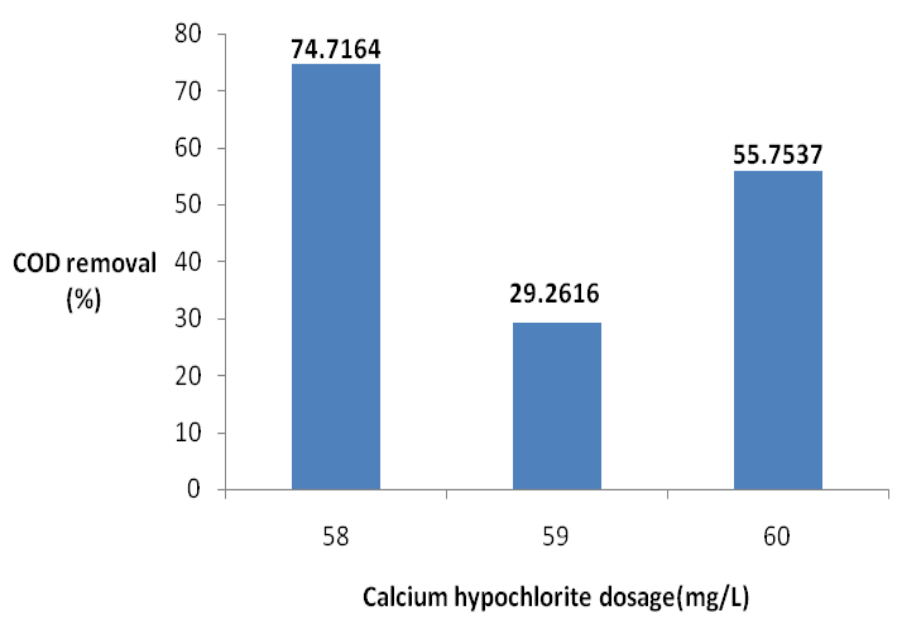

Figure 3. The comparison of COD removal percentage of each activated sludge treatment variation

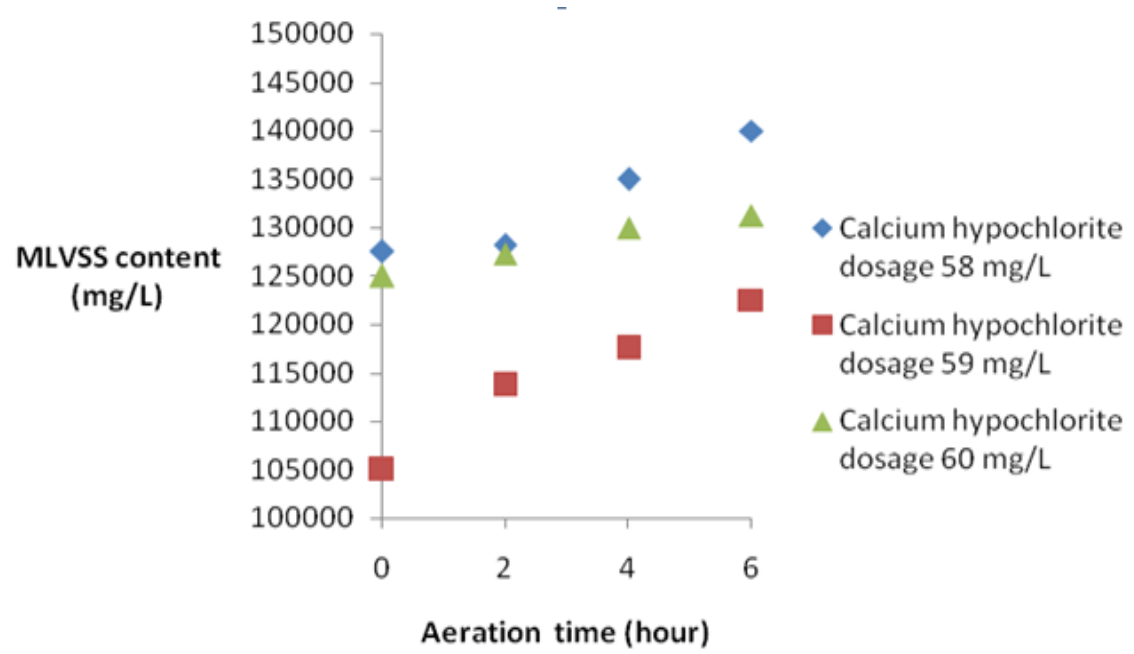

Figure 4. MLVSS profile during activated sludge treatment process

\section{MLVSS Profile During Activated Sludge Treatment Process}

Following figure illustrates MLVSS profile during tapioca wastewater activated sludge treatment. In all variation calcium hypochlorite dosage, MLVSS content will continue to increase with increasing aeration time. It indicates that activated sludge treatment could take place effectively due to microorganisms growth which shown by the increase of MLVSS.

As COD removal percentage data trend, MLVSS content also has highest value in activated sludge treatment using smallest calcium hypochlorite dosage variation for tapioca astewater pretreatment. These phenomenons can occur because hydrochloric acid compound $(\mathrm{HOCl})$ and hypochlorite ion $\left(\mathrm{OCl}^{-}\right)$, product of calcium hypochlorite hydrolisis, is very reactive to cell bacterial especially in excessive addition (Parga, Shukla, \& Pedroza, 2003).

\section{CONCLUSIONS}

The main conclusion of this research result is pre-chlorination can be applied as tapioca wastewater pre-treatment prior to activated sludge treatment. This study shows that addition of aeration time for each variation of calcium hypochlorite dosage generally will increase MLVSS and decrease COD content. In order to achieve smallest value of COD effluent in activated sludge treatment, the condition operations such calcium hipochlorite dosage $60 \mathrm{mg} / \mathrm{L}$ and aeration time 4 hour must be applied. However, addition of 58 
$\mathrm{mg} / \mathrm{L}$ calcium hypochlorite results highest MLVSS and percentage of COD removal.

\section{ACKNOWLEDGEMENT}

We would like to thank Indonesian Directorate General of Higher Education which has funded this research programme.

\section{REFERENCES}

Central Java Provincial Act No. 10/2004 Concerning the Quality Standard of the Waste Water.

Chan, Y.J. M.F., Chong, L.L., Chung. D.G., Hassel. (2009). A Review on Anaerobic-Aerobic Treatment of Industrial and Municipal Wastewater. Chemical Engineering Journal, 155(1),1-18.

Deborde, M. and U.V., Gunten. (2008). Reactions of Chlorine With Inorganic and Organic Compounds During Water Treatment-Kinetics and Mechanisms: A Critical Review. Water Research, 42(1),1351.

Elmagd, A.M.A. and M.S., Mahmoud. (2014).Tannery Wastewater Treatment Using Activated Sludge Process System (Lab Scale Modeling). International Journal of Engineering and Technical Research, 2(5),21-28.

Ferraz, F.M. A.T., Bruni. V.L.D., Bianchi. (2009). Performance of an ABR in Treatment of Cassava Wastewater. Brazilian Journal of Microbiology, 40(1),48-53.

Ji, B. K., Yang. W, Chen. J., Wang. L., Zhu. (2016). Impacts of Dissolved Oxygen and Initial Sludge Concentrations on Aerobic Stabilization of Sewage Sludge. Polish. Journal of Environmental Studies, 25(1),153-157.

Kumar, K. G.K., Singh. M.G., Dastidar. T.R., Sreekrishnan. (2014). Effect of Mixed Liquor Volatile Suspended Solids (MLVSS) and Hydraulic Retention Time (HRT) on the Performance of Activated Sludge
Process During the Biotreatment of Real Textile Wastewater. Water Resources and Industry, 5(1),1-8.

Mulyani, H. dan M.E., Prasadja. (2014). Study of Chlorination Application in Tapioca Wastewater for Cyanide Removal. Waste Technology, 2(2),41-43.

Mulyani, H. S.B., Sasongko. D., Soetrisnanto. (2012). Pengaruh Preklorinasi Terhadap Proses Start Up Pengolahan Limbah Cair Tapioka Sistem Anaerobic Baffled Reactor. Momentum, 8(1),1- 27.

Parga, J.R. S.S., Shukla. F.R.C., Pedroza. (2003). Destruction of Cyanide Waste Solutions Using Chlorine Dioxide, Ozone and Titania Sol, Waste Management, 23(1), 183191.

Pickup, J. (2010). Environmental Safety of Halogenated by-products From Use of Active Chlorine. Eurochlor Science Dossier.

Riyanti, F. P. Lukitowati. Afrilianza. (2010). Proses Klorinasi Untuk Menurunkan Kandungan Sianida dan Nilai KOK Pada Limbah Cair Tepung Tapioka. Jurnal Penelitian Sains, 13(3),34-39.

Salem. M., Mostafa. W., Ibrahim. (2014). Influence of Different Chlorine Injection Methods on the Filamentous Bulking Problem. International Journal of Chemical, Environmental \& Biological Sciences, 2(1),7-11.

Santoso, B. (2010).Wastewater Treatment Process in Tapioca Industry. Jurnal Ilmiah Teknologi \& Rekayasa, 15(3),213-220.

Schnurer, A. and A. Jarvis (2009). Microbiological Handbook for Biogas

Plants.http://www.ocfarmbiogas.ca. Accessed 28 July 2011.

Setyawati, R. K.K., Hirayama. H., Kaneko, K., Hirayama. (2011). Current of Tapioca Starch Wastewater (TSW) Management in 
Indonesia. World Applied Science Journal. 14(5):658-665.

Subramani, T. and Arulalan, K. (2012). Evaluation of the Efficiency of Surface Aerator in the Activated Sludge Process Treatment of Food Processing Effluent. International Journal of Modern Engineering Researc, 2(4),1518-1528.
Takdastan, A. A.A., Azimit. N., Jaafarzadeh. (2010). Biological Excess Sludge Reduction in Municipal Wastewater Treatment by Chlorine. Asian Journal of Chemistry, 22(3),1165-1174. 